\title{
Differential expression of CD25 (interleukin-2 receptor) on lamina propria $T$ cells and macrophages in the intestinal lesions in Crohn's disease and ulcerative colitis
}

\author{
M Y Choy, J A Walker-Smith, C B Williams, T T MacDonald
}

\begin{abstract}
Many interleukin-2 receptor (CD25) bearing cells can be identified by alkaline phosphatase immunohistochemistry in the diseased intestinal lamina propria of children with Crohn's disease or ulcerative colitis, but rarely in normal intestine. In both diseases, the CD25+ cells are present as aggregates in the lamina propria below the epithelium, and constitute a large proportion of the lamina propria mononuclear cells. In Crohn's disease, but not ulcerative colitis, CD25+ cells are abundant in the submucosa. The CD25+ cells in Crohn's disease are $58-88 \% \mathrm{CD} 3+, \mathrm{CD} 4+, \mathrm{CD} 8-$, indicating that they are $T$ cells, whereas in ulcerative colitis the CD25+ cells are greater than $80 \%$ CD3-, CD4+, HLA-DR+, indicating that they are macrophages. Thus, differential expression of CD25 on $T$ cells and macrophages serves to distinguish the immunologic lesions in ulcerative colitis and Crohn's disease.
\end{abstract}

The aetiology and pathogenesis of the idiopathic inflammatory bowel diseases remain unknown. Whether the trigger for the development of the two most common disorders, ulcerative colitis and Crohn's disease, is bacterial, viral, dietary, or environmental, there is general agreement that immune mechanisms are probably of importance. Both ulcerative colitis and Crohn's disease are characterised by an influx of inflammatory cells into the diseased mucosa and local production of soluble mediators of inflammation has been shown. ${ }^{1-4}$ There are increased numbers of plasma cells in the affected mucosa in inflammatory bowel disease. ${ }^{5}$ Likewise, there are increased numbers of $T$, cells, but the ratio of CD4 to CD8 cells is the same as in control subjects ${ }^{6}$ and, paradoxically, it has been reported in immunohistochemical studies that phenotypic markers of $T$ cell activation are absent from diseased mucosa. ${ }^{6-8}$ In contrast, mononuclear cells isolated from Crohn's mucosa do show a slight increase in the expression of activation markers (including CD25), but the source of origin of these cells (lamina propria or Peyer's patch) was not established. ${ }^{9}$

We have recently shown, using an in vitro model, that $T$ cell activation in human fetal small intestine induces numerous CD25+ lamina propria $T$ cells, increases epithelial proliferation and epithelial cell HLA-DR expression, increases HLA-DR and CD25 expression on lamina propria macrophages, and results in aggregates of macrophages in the lamina propria. ${ }^{10-12}$ These features are reminiscent of some of the immunopathological changes in inflammatory bowel disease. CD25 (the p55 chain of the interleukin-2 receptor) is a marker of activation in a number of cell types, including $T$ cells, $B$ cells, and macrophages. ${ }^{13}$ Hence, we decided to analyse in detail CD25 expression in the inflamed bowel of children with inflammatory bowel disease to determine the role of the activated $T$ cell in these lesions. We now show, using sensitive methodology, that activated $T$ cells $(C D 25+)$ are abundant in the lamina propria and submucosa in Crohn's disease but are less common in ulcerative colitis. There are, however, CD25 + cells in ulcerative colitis but these are mostly macrophages.

\section{Methods}

\section{INFLAMMATORY BOWEL DISEASE TISSUES}

\section{Crohn's tissue}

Intestine from 12 children with active Crohn's disease was used in this study (Table). The histological diagnosis of Crohn's disease or ulcerative colitis was based on the criteria of Chong et al. ${ }^{14}$ Eleven of the 12 children with diseased terminal ileum underwent right hemicolectomies and colonic tissue was also obtained. In six of these disease was present in the colon.

Details of the patients with inflammatory bowel disease

\begin{tabular}{|c|c|c|c|c|}
\hline & Sex & $\begin{array}{l}\text { Age at } \\
\text { surgery } \\
\text { (yrs) }\end{array}$ & $\begin{array}{l}\text { Duration } \\
\text { of disease } \\
\text { (yrs) }\end{array}$ & Treatment before surgery \\
\hline \multicolumn{5}{|c|}{ Crohn's patients } \\
\hline 1 & $M$ & $16 \cdot 2$ & $8 \cdot 1$ & $\begin{array}{l}\text { Asacol, azath }(75 \mathrm{mg} / \text { day }) \text { pred } \\
(10 \mathrm{mg} / \text { day })\end{array}$ \\
\hline $\begin{array}{l}2 \\
3 \\
4 \\
5\end{array}$ & $\begin{array}{l}\mathbf{F} \\
\mathbf{M} \\
\mathbf{M} \\
\mathbf{F}\end{array}$ & $\begin{array}{l}13 \cdot 2 \\
16 \cdot 5 \\
17 \cdot 1 \\
15 \cdot 2\end{array}$ & $\begin{array}{l}3 \\
3 \cdot 8 \\
3 \cdot 3 \\
4 \cdot 8\end{array}$ & $\begin{array}{l}\text { Flexical } \\
\text { Asacol, Flexical } \\
\text { None } \\
\text { Pred ( } 30 \mathrm{mg} / \text { alt days), asacol, } \\
\text { azath ( } 50 \mathrm{mg} / \text { day })\end{array}$ \\
\hline $\begin{array}{r}6 \\
7 \\
8 \\
9 \\
10 \\
11 \\
12\end{array}$ & $\begin{array}{l}M \\
M \\
F \\
F \\
F \\
M \\
F\end{array}$ & $\begin{array}{l}16 \cdot 5 \\
10 \cdot 2 \\
12 \cdot 8 \\
11 \cdot 8 \\
11 \cdot 6 \\
14.9 \\
11 \cdot 5\end{array}$ & $\begin{array}{l}7 \cdot 2 \\
0 \cdot 7 \\
0 \cdot 8 \\
2 \cdot 7 \\
4 \cdot 2 \\
1 \cdot 9 \\
1 \cdot 6\end{array}$ & $\begin{array}{l}\text { Pred ( } 5 \mathrm{mg} / \text { alt day), asacol } \\
\text { Pred ( } 40 \mathrm{mg} / \text { day) } \\
\text { Asacol, pred (10 mg/day) } \\
\text { Flexical } \\
\text { Asacol } \\
\text { Asacol, pred ( } 5 \mathrm{mg} / \text { alt day) } \\
\text { Flexical }\end{array}$ \\
\hline \multicolumn{5}{|c|}{ Ulcerative colitis patients } \\
\hline & $\begin{array}{l}\mathrm{M} \\
\mathrm{F}\end{array}$ & $\begin{array}{l}10.5 \\
11.6\end{array}$ & $\begin{array}{l}0.8 \\
0.1\end{array}$ & $\begin{array}{l}\text { Asacol, pred ( } 25 \mathrm{mg} / \text { alt days }) \\
\text { Pred (10 mg/alt days), pred } \\
\text { enemas }\end{array}$ \\
\hline $\begin{array}{l}15 \\
16 \\
17\end{array}$ & $\begin{array}{l}\mathbf{M} \\
\mathbf{M} \\
\mathbf{M}\end{array}$ & $\begin{array}{l}16 \cdot 3 \\
13 \cdot 8 \\
16 \cdot 5\end{array}$ & $\begin{array}{l}1 \cdot 3 \\
0 \cdot 5 \\
4 \cdot 1\end{array}$ & $\begin{array}{l}\text { Pred }(20 \mathrm{mg} / \text { day }) \text {, asacol } \\
\text { Pred }(10 \mathrm{mg} / \text { day }) \text {, pred enemas } \\
\text { None }\end{array}$ \\
\hline
\end{tabular}

Pred = prednisolone; azath $=$ azathioprine Asacol given to all patients at $800 \mathrm{mg} /$ day, except patient $15(1200$ mg/day).
Gastroenterology, St Bartholomew's Hospital M Y Choy J A Walker-Smith C B Williams Correspondence to: Dr T T MacDonald. Accepted for publication 22 January 1990 
Within 10 minutes of resection, samples of grossly diseased tissue, more normal looking tissue proximal to the lesion close to the resection margin, and colon were dissected out and placed in cold tissue culture medium. They were immediately transported to the laboratory where they were divided into $1 \mathrm{~cm}^{2}$ pieces, snap frozen in liquid nitrogen, and stored at $-70^{\circ} \mathrm{C}$.

\section{Ulcerative colitis}

Colon was obtained from five children undergoing partial or total colectomy for active ulcerative colitis (Table). Immediately after resection the bowel was opened to visualise the mucosa and samples of tissue were taken from diseased areas and macroscopically normal areas if these were present. The tissues were processed as for the Crohn's disease samples.

\section{CONTROL TISSUES}

Histologically normal small intestine was obtained from three of the Crohn's patients (Table, patients 1, 3, and 4) proximal to the site of disease and close to the resection margin. Resected ileum from a 65 year old woman with postoperative complications after large bowel surgery for reasons unrelated to inflammatory bowel disease was also studied. Finally, jejunal biopsy specimens from three other patients were studied (all female). These patients were aged 5 months, 35 years, and 54 years, and in all cases jejunal morphology was normal.

Biopsy specimens were also obtained from the transverse colon or caecum of five children with a clinical history suggestive of inflammatory bowel disease but in whom the specimens were histologically normal. These five patients comprised four boys and one girl, aged between 5 and 14 years.

\section{MONOCLONAL ANTIBODIES AND}

IMMUNOHISTOCHEMICAL STAINING

Frozen sections $(8 \mu \mathrm{m})$ of intestine were cut and stained immunohistochemically using the indirect alkaline phosphatase antialkaline phosphatase technique. ${ }^{15}$ Fast red was used to visualise staining and the slides were counterstained with Mayer's haematoxylin. Endogenous brush border alkaline phosphatase served as a positive internal control of substrate activity for each staining run. The monoclonal antibodies used were anti-CD3, anti-CD4, and anti-CD8 (Becton-Dickinson, Mountain View, CA, USA); anti-CD25 (a gift from Dr T Waldmann, National Institutes of Health, Bethesda, MD, USA); and anti-HLA-DR (Dako Ltd, High Wycombe, Bucks).

To determine whether CD25 cells expressed CD3, CD4, CD8, or HLA-DR, a sequential staining technique was used as described elsewhere. ${ }^{16}{ }^{17}$ Briefly, tissues were first stained with anti-CD3, CD4, CD8, or HLA-DR, or without primary antibody, by the indirect immunoperoxidase technique to give a brown reaction product. The sections were then washed and stained with anti-CD25 using fast red and the alkaline phosphatase antialkaline phosphatase technique. Any cell expressing, for example, $\mathrm{CD} 3$, would stain brown from the immunoperoxidase. If that cell also expressed CD25 it would stain brownish/red (purple). Importantly, any cell expressing $\mathrm{CD} 25$ but not $\mathrm{CD} 3$ would stain red.

\section{QUANTITATION}

The number of lamina propria cells expressing CD25 in single stained slides was determined by making differential counts of cells staining red $(\mathrm{CD} 25+)$ to unstained cells (identified by their blue nuclei). At least 500 cells were counted in different parts of the lamina propria. The CD25 cells are expressed as a percentage of the total number of cells counted. As will be shown below, $\mathrm{CD} 25$ + cells were frequently present as subepithelial aggregates which were noted but were impossible to quantitate. All differential counts were therefore made in areas of the lamina propria excluding the subepithelial zone.

The extent to which immunoperoxidase staining with anti-CD3, CD4, CD8 or anti-HLA-DR blocked anti-CD25 staining with fast red was determined by first determining the percentage of red CD25 + cells in an area of lamina propria, followed by determining the percentage of cells remaining red in a serial section after blocking with a given monoclonal antibody and the peroxidase technique. Full details of this procedure and its use in establishing the phenotype of lamina propria cells have been published elsewhere. ${ }^{718}$ The percentage reduction in CD25 + cells staining red before staining with a given monoclonal antibody and the peroxidase

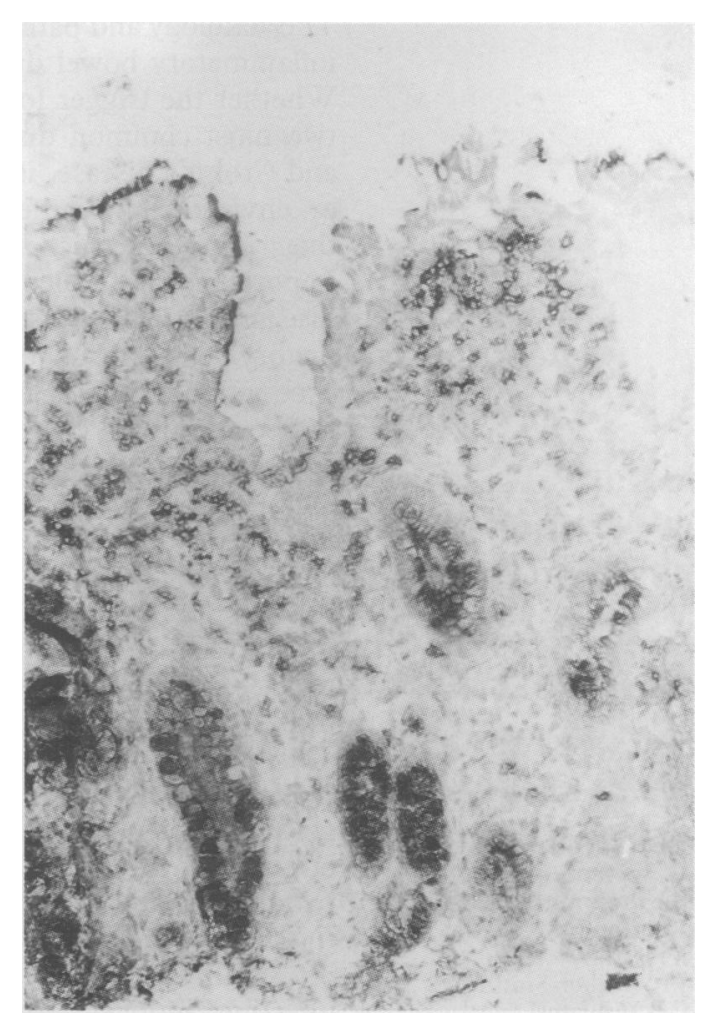

Figure 1:CD25+ cells in a well oriented section of terminal ileum from a child with active Crohn's disease. Note that there is a small subepithelial aggregate and that the CD25+cells are also scattered throughout the lamina propria. (Alkaline phosphatase, original magnification $\times 100$.) 
technique was taken as the percentage of CD25+ cells also expressing the antigen recognised by the first monoclonal.

\section{STATISTICS}

Data points in any given group were first tested to determine if they conformed to samples from a normally distributed population. Results are expressed as mean (SD). Differences between groups were compared by analysis of variance.

\section{Results}

\section{CD25 EXPRESSION IN NORMAL INTESTINAL} MUCOSA AND IN CROHN'S DISEASE AND ULCERATIVE COLITIS

In normal small and large intestinal lamina propria, CD25 + cells were rarely seen. A few large subepithelial cells stained weakly positive and there were occasional small round brightly staining cells in the lamina propria. The thymus dependent zones of ileal Peyer's patches, however, did contain CD25 + cells.

In noticeable contrast there was extensive CD25 expression in the diseased mucosa of the children with inflammatory bowel disease. In Crohn's ileal lesions, there were subepithelial aggregates of $\mathrm{CD} 25+$ cells which varied in size, as well as CD25+ cells scattered throughout the lamina propria (Fig 1). The different morphological appearance of the subepithelial cells and those deeper in the lamina propria is illustrated in Figure 2. Counts of CD25+ cells showed that they made up $16-54 \%$ of the lamina propria

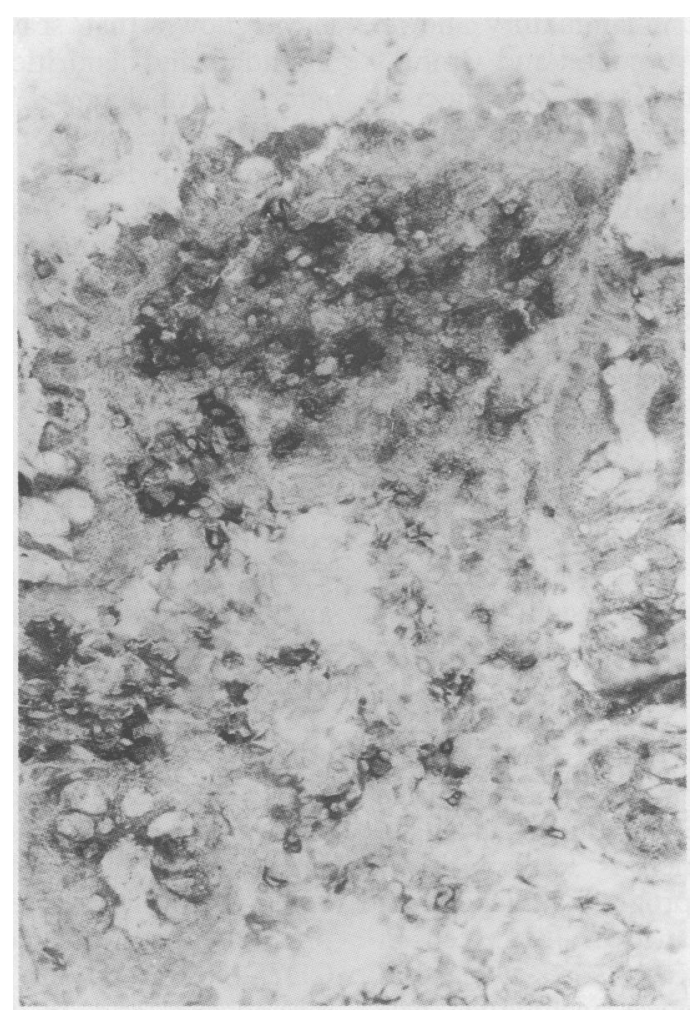

Figure 2: CD25 + cells are seen in two different sites in the bowel in Crohn's disease. The subepithelial aggregates contain large cells whereas deeper in the mucosa the CD25+cells are smaller with membrane staining. (Alkaline phosphatase, original magnification $\times 200$.)

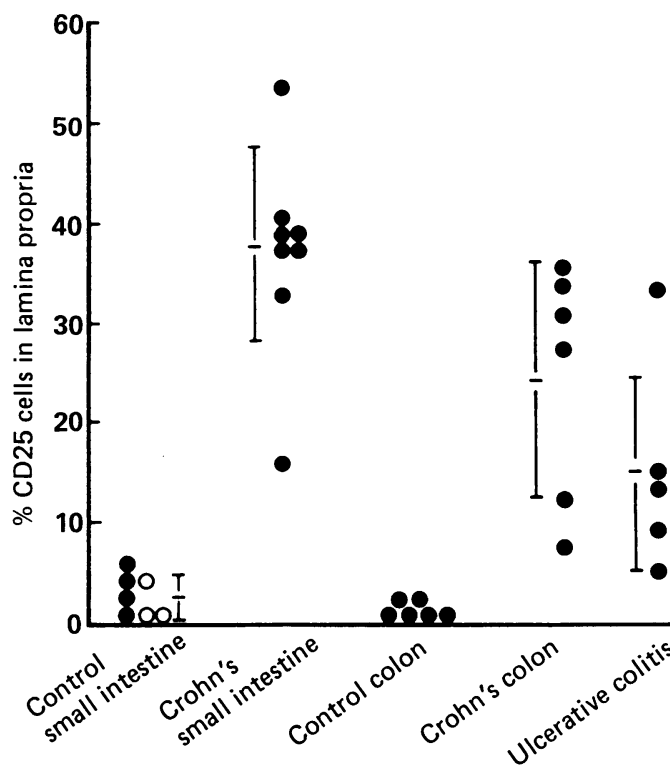

Figure 3: The percentage of CD25+ cells in the small intestinal and colonic lamina propria of children with Crohn's disease, ulcerative colitis, and in control tissues free of disease. Counts were made of individual CD25 + cells distant from the subepithelial aggregates. Open circles are the counts in histologically normal small bowel of children with more distal Crohn's disease. Compared with control small intestine there were significantly more $(p<0.00001$, analysis of variance $)$ $C D 25+$ cells in Crohn's small intestine. In the colon in both ulcerative colitis and Crohn's colitis there were more $(p<0.01$, both groups) CD25+ lamina propria cells than in control colon.

nucleated cells (Fig 3). In Crohn's colitis, there was essentially the same distribution of CD25+ subepithelial aggregates and scattered cells throughout the lamina propria as in the small bowel. The lymphoid follicles prominent in Crohn's disease in the colon and ileum also contained numerous CD25+ cells, and there were also positive cells in the inflamed submucosa, including the muscle, and around the vessels. CD25+ intraepithelial lymphocytes were only occasionally seen. There was no relation between the frequency of $\mathrm{CD} 25+$ cells and steroid treatment. The patient on the highest dose of steroids $(40 \mathrm{mg}$ ) had abundant CD25+ cells in his lamina propria. In ulcerative colitis, CD25 + cells were also present in essentially the same distribution as in Crohn's colitis, making up $5-33 \%$ of lamina propria cells (Fig 3 ) and forming subepithelial aggregates.

NATURE OF THE CD25 + CELLS IN INFLAMMATORY BOWEL DISEASE

It was obvious from the onset of this study that the morphology of the CD25 + cells in inflammatory bowel disease varied greatly (Fig 2). The subepithelial aggregates in both Crohn's disease and ulcerative colitis mostly contained large foamy cells, and the cells deeper in the lamina propria, especially in Crohn's disease, were small with dense membrane staining. To determine the phenotype of the CD25+ cells, a series of blocking experiments with a panel of monoclonal antibodies was carried out.

In both Crohn's colitis and ileitis, red CD25 immunoalkaline phosphatase staining was substantially blocked $(60-90 \%)$ by prior staining of the sections with anti-CD3 by the immuno- 
peroxidase method (Fig 4). In contrast, in ulcerative colitis only 5-22\% of the CD25 staining was blocked by anti-CD3 immunoperoxidase (Fig 4)

In Crohn's colitis and ileitis the red anti-CD25 staining was almost completely blocked $(>95 \%)$ by anti-CD4 immunoperoxidase but hardly affected $(<5 \%)$ by prior anti-CD8 peroxidase staining (not shown). Thus, most of the CD25+ cells in Crohn's disease are $\mathrm{CD} 3+, 4+, 8-$. Anti-CD4 and anti-HLA-DR almost completely blocked CD25 staining in ulcerative colitis (>95\%, not shown) which would indicate that the CD25 + cells in this condition are mostly CD3-, CD4+, HLA-DR + , the phenotype of lamina propria macrophages and dendritic cells.

Activated B cells can also express CD25, but the complete blocking of CD25 staining with CD4, which is not expressed by B cells, makes it unlikely that CD25+ B cells are a major feature of the lesions in inflammatory bowel disease.

Quantitation of CD25 blocking was only possible where CD25+ cells were scattered in the lamina propria (as detailed in the methods). The subepithelial aggregates of red staining CD25+ cells in both ulcerative colitis and Crohn's disease, however, were almost completely blocked with anti-CD4 and antiHLA-DR immunoperoxidase, confirming that these cells were mostly macrophages. There were $\mathrm{CD} 3$ + cells within these aggregates, but it was impossible to determine their actual percentage.

\section{Discussion}

There have been a number of previous studies on the lymphoid/myeloid infiltrate in the mucosa of patients with chronic inflammatory bowel disease. In both ulcerative colitis and Crohn's disease there is an increased lymphocytic infiltrate compared with normal bowel, but the ratio of CD4 to $\mathrm{CD} 8$ cells is unchanged. ${ }^{6}$ There is a pronounced macrophage infiltrate and changes in macrophage/dendritic cell populations in inflammatory bowel disease, ${ }^{18-21}$ and there is also evidence that the macrophages in this disorder are in an increased state of activation compared with normal lamina propria macrophages. ${ }^{2122}$ Crohn's disease bears the stigmata of a $\mathrm{T}$ cell mediated reaction, but, surprisingly, a number of previous immunohistologic or immunofluorescence studies have failed to observe phenotypic markers of $T$ cell activation, such as $\mathrm{CD} 25$, as a major feature of the lesion. ${ }^{6-8}$

The major observation of this study is that, contrary to these previous reports, CD25 + cells are abundant in the gut of children with inflammatory bowel disease. These cells were detected using alkaline phosphatase immunohistochemistry, whereas previous studies had used immunofluorescence, which is less sensitive. While this work was in progress, independent confirmation of the abundance of CD25 + cells in inflammatory bowel disease, also using the immunoalkaline phosphatase technique, was published, ${ }^{23}$ however the phenotype of the cells was not established, although it was considered that they were mostly macrophages.

$\mathrm{CD} 25+$ cells were rare in the lamina propria of

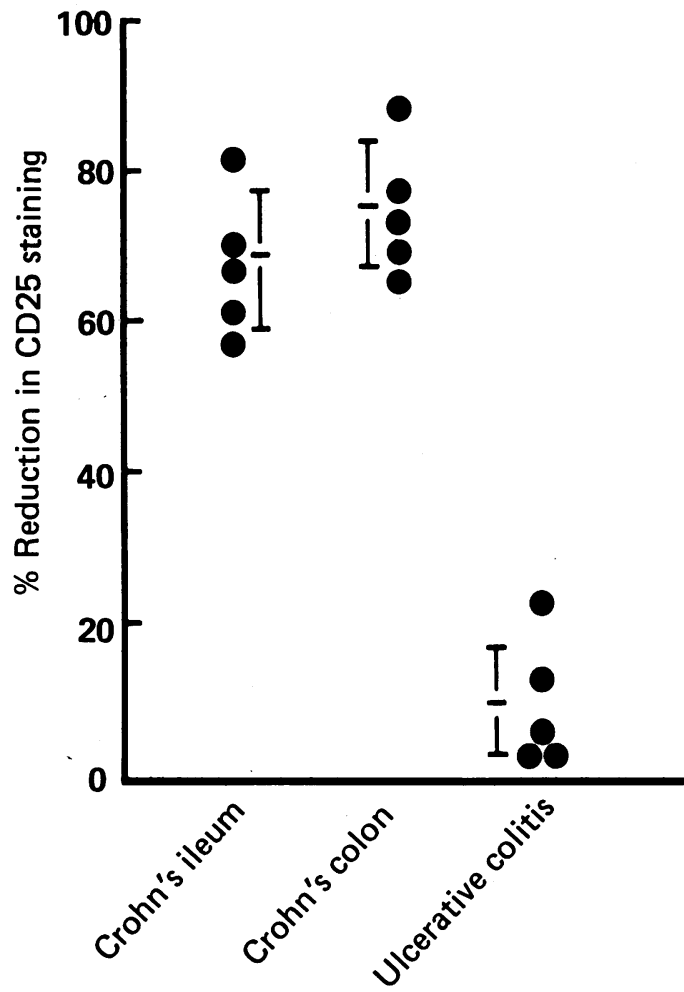

Figure 4: $C D 3$ peroxidase blocking of CD25 immunoalkaline phosphatase staining in Crohn's disease and ulcerative colitis. In both Crohn's ileitis and Crohn's colitis CD3 blocked 58In both Crohn's ileitis and Crohn's colitis CD3 blocked
$90 \%$ of the CD25 staining. In ulcerative colitis, CD25 staining was only marginally $(10 \%)$ blocked $(p<0.00001$, Crohn's disease v ulcerative colitis).

normal small bowel and colon. Most of the positive cells were large and were immediately below the surface epithelium. Morphologically, they resembled macrophages. Other studies have shown that scavenger macrophages are abundant and dendritic cells are rare subepithelially in normal bowel. ${ }^{1921} 24$ There are no other similar studies on CD25 expression in the gut in man, but in isolated mucosal lymphocytes (a mixture of Peyer's patch and lamina propria cells) from non-human primates ${ }^{25}$ about $15 \%$ of cells are CD25+. These are mostly $\mathrm{T}$ cells. Species differences or diet, or both, may account for these apparently different results. In addition, we did notice CD25 + cells in the T cell zones in sections of normal human Peyer's patches. If similar cells are present in nonhuman primate Peyer's patches, they could contribute towards the apparent high level of CD25 expression in mixtures of lamina propria and Peyer's patch cell suspensions from nonhuman primate mucosa. In inflamed bowel in ulcerative colitis and Crohn's disease, however, CD25 + cells were abundant. There were subepithelial aggregates of large foamy cells which also expressed CD4 and HLA-DR. These probably correspond to the subepithelial macrophage aggregates in normal bowel which are weakly CD25+ and their increased CD25 expression is probably a consequence of immune stimulation. $\mathrm{CD} 25$ + macrophages are seen in the lung in sarcoidosis $^{26}$ and in vitro experiments have shown that interferon gamma can induce CD25 on macrophages. ${ }^{26} 27$ In the gut we have also previously shown that $T$ cell activation in explants of human fetal small bowel in vitro also 
results in the appearance of $\mathrm{CD} 25+, \mathrm{CD} 3-, 4+$ cells in the lamina propria. ${ }^{28}$ We have also shown that activated $\mathrm{T}$ cells in the explants secrete interferon gamma. ${ }^{11}$ It is possible that this may be the mediator responsible for increased CD25 expression on intestinal macrophages in inflamed tissues. Nevertheless, other mediators are also probably capable of inducing CD25 expression on macrophages and so macrophage CD25 expression may be a general feature of inflammation rather than a direct indication of a local production of interferon gamma by activated $T$ cells.

Double staining showed that in ulcerative colitis most of the CD25+ cells were CD3-, $\mathrm{CD} 4+$ and were therefore likely to be macrophages. It is unlikely that they are dendritic cells because in ulcerative colitis these are stellate cells with long cytoplasmic processes. ${ }^{20}$ However, in Crohn's disease most of the CD25+ cells were $\mathrm{CD} 3+, \mathrm{CD} 4+, \mathrm{CD} 8-(\mathrm{T}$ cells). In addition, in single stained specimens many of the CD25+ cells had the morphological appearance of lymphocytes. CD25 is expressed very early after $T$ cell activation, gene expression being detectable as early as four to six hours after stimulation. ${ }^{29}$ With continued activation, however, CD25 expression diminishes. ${ }^{14}$ Thus, in Crohn's disease the CD25 + T cells are probably recently activated, perhaps having recently extravasated from the blood. The antigen(s) to which these T cells are responding is unknown, however, and their identification would be a major step forward in our understanding of Crohn's disease. The $T$ cell response is likely to be polyclonal in response to a number of antigens since recent studies on the diversity of $\mathrm{T}$ cell receptors found on gut $\mathrm{T}$ cells in Crohn's disease gave no evidence of a monoclonal or oligoclonal response. ${ }^{30}$ In dealing with inflamed mucosa, however, there is always the problem that the $T$ cells responding to antigen may be diluted out by a non-specific influx of $T$ cells into the mucosa.

$\mathrm{CD} 4+\mathrm{T}$ cells predominate in the normal lamina propria, ${ }^{31}$ and in Crohn's disease they are increased. ${ }^{632}$ In a recent case report, a patient with Crohn's disease was described who developed HIV infection. ${ }^{33}$ In association with the loss of CD4+ cells from his blood, and presumably his mucosa, ${ }^{34}$ his Crohn's disease went into extended complete remission for the first time in an 18 year history. This observation, taken together with the results of this present study, indicates that activated CD4 + T cells may be responsible for the lesion in Crohn's disease, presumably by the production of inflammatory mediators. That these cells are not as abundant in ulcerative colitis serves to emphasise the differences between Crohn's disease and ulcerative colitis, which are also evident histopathologically..$^{35}$

T T MacDonald is a Wellcome Senior Lecturer. M Choy is supported by a grant from the National Foundation for Ileitis and Colitis, New York. This work was also supported by Crohn's in Childhood Research Appeal.

1 Hadfield G. The primary histological lesion of regional ileitis. Lancet 1939; ii: 773-5.

2 Rappaport H, Burgoyne FH, Smetana HF. The pathology of regional enteritis. Milit Surg 1951; 109: 463-502.

3 Zifroni A, Treves AJ, Sachar DB, Rachmilewitz D. Prostanoid synthesis by cultured intestinal epithelial and mononuclear cells in inflammatory bowel disease. Gut 1983; 24: 659-65.

4 Lauritsen K, Laursen LS, Bukhave K, Rask-Madsen J. In vivo profiles of eicosanoids in ulcerative colitis, Crohn's colitis, and Clostridium difficile colitis. Gastroenterology 1988; 95: 11-7.

5 Brandtzaeg P. The B cell system. In: Brostoff J, Challacombe SB, eds. Food allergy and intolerance. London: Bailliere Tindall, 1987: 118-55.

6 Selby WS, Janossy G, Bofill M, Jewell DP. Intestinal lymphocyte subpopulations in inflammatory bowel disease: an analysis by immunohistological and cell isolation techniques. Gut 1984; 25: 32-40

7 Konttinen YT, Bergroth V, Nordstrom D, SegerbergKonttinen M, Seppala K, Salaspuro M. Lymphocyte activation in vivo in the intestinal mucosa of patients with Crohn' disease. F Clin Lab Immunol 1987; 22: 59-63.

8 Fais S, Pallone F, Squarcia O, et al. HLA-DR antigens on colonic epithelial cells in inflammatory bowel disease: 1 . Relation to the state of activation of lamina propria lymphocytes and to the epithelial expression of other surface markers. Clin Exp Immunol 1987; 68: 605-12.

9 Pallone F, Fais S, Squarcia O, Biancone L, Pozzilli P Boivirant $M$. Activation of peripheral blood and intestinal lamina propria lymphocytes in Crohn's disease. In vivo state of activation and in vitro response to stimulation as defined of activation and in vitro response to stimulation as defined
by the expression of early activation antigens. Gut 1987; 28: by the expr

10 MacDonald TT, Spencer J. Evidence that activated mucosal T cells play a role in the pathogenesis of enteropathy in human small intestine. $\mathcal{F} \operatorname{Exp} M e d$ 1988; 167: 1341-9.

11 MacDonald TT, Weinel A, Spencer J. HLA-DR expression in fetal human small intestinal epithelium. Gut 1988; 29 1342-8.

12 MacDonald TT, Spencer JM. The consequences of T cell activation in human small intestine. In: McDermott RM, ed. Inflammatory bowel disease: current status and future approaches. Amsterdam: Elsevier Science, 1988: 107-12.

13 Smith KA. Interleukin-2: inception, impact and implications. Science 1988; 240: 1164-76.

14 Chong SKP, Bartram C, Campbell CA. Williams CB Blackshaw AJ, Walker-Smith JA. Chronic inflammatory bowel disease in childhood. $\mathrm{Br}$ Med f 1982; 284: 101-3.

15 Isaacson PG, Wright DH. Immunocytochemistry of lymphoreticular tumours. Immunocytochemistry. In: Polak JM, van Noorden S, eds. Practical applications in pathology $E$ biology. Bristol: John Wright \& Sons, 1983: 249

16 Spencer J, MacDonald TT, Isaacson PG. Heterogeneity of non-lymphoid cells expressing HLA-D region antigens in human fetal gut. Clin Exp Immunol 1987; 67: 415-24.

17 Spencer J, MacDonald TT, Diss TC, Walker-Smith JA, Ciclitira PJ, Isaacson PG. Changes in intraepithelial lymphocyte subpopulations in coeliac disease and enteropathy associated $T$ cell lymphoma (malignant histiocytosis of the intestine). Gut 1989; 30: 339-46.

18 Selby WS, Poulter LW, Hobbs S, Jewell DP, Janossy G. Heterogeneity of HLA-DR-positive histiocytes in human intestinal lamina propria: a combined histochemical and immunohistological analysis. 7 Clin Pathol 1983; 36: 379 84.

19 Allison MC, Cornwall S, Poulter LW, Dhillon AP, Pounder RE. Macrophage heterogeneity in normal colonic mucos and in inflammatory bowel disease. Gut 1988; 29: 1531-8.

20 Seldenrijk CA, Drexhage HA, Meuwissen SGM, Pals ST, Meijer CJLM. Dendritic cells and scavenger macrophages in chronic inflammatory bowel disease. Gut 1989; 30:484-91.

21 Mahida YR, Patel S, Gionchetti P, Vaux D, Jewell DP Macrophage subpopulations in lamina propria of normal and
inflamed colon and terminal ileum. Gut 1989; 30: 826-34.

22 Mahida YR, Wu K, Jewell DP. Enhanced production of interleukin $1-\beta$ by mononuclear cells isolated from mucosa with active ulcerative colitis or Crohn's disease. Gut 1989 ; 30: 835-8.

23 Mahida YR, Patel S, Wu K, Jewell DP. Interleukin 2 recepto expression by macrophages in inflammatory bowel disease. Clin Exp Immunol 1988; 74: 382-6.

24 Hume DA, Allan W, Hogan PG, Doe WF. Immunohistochemical characterisation of macrophages in human liver and gastrointestinal tract: Expression of CD4, HLA-DR, $\mathrm{OKM} 1$, and the mature macrophage marker $25 \mathrm{~F} 9$ in norma and diseased tissue. $\mathcal{F}$ Leukocyte Biol 1987; 42: 474-84.

25 Zeitz M, Greene WC, Peffer NJ, James SP. Lymphocytes isolated from the intestinal lamina propria of normal nonhuman primates have increased expression of genes nonhuman primates have increased expression of genes 647-55.

26 Hancock WW, Muller WA, Cotran RS. Interleukin 2 receptors are expressed by alveolar macrophages during pulmonary sarcoidosis and are inducible by lymphokin treatment of normal human lung macrophages, blood monocytes, and monocyte cell lines. $\mathcal{F}$ Immunol 1987; 138 : $185-90$

27 Holter W, Goldman CK, Casabo L, Nelson DL, Greene WC Waldman TA. Expression of functional IL 2 receptors by lipopolysaccharide and interferon-stimulated human monocytes. F Immunol 1987; 138: 2917-22.

28 Monk TJ, Spencer J, Cerf-Bensussan N, MacDonald TT. Activation of mucosal T-cells in situ with anti-CD3 antibody: phenotype of the activated $T$ cells and their distribution within the mucosal micro-environment. Clin Exp Immunol 1988; 74: 216-22.

29 Reed JC, Abidi AH, Alpers JD, Hoover RG, Robb RJ, Nowell $P C$. Effect of and cyclosporin $A$ and dexamethasone on interleukin 2 receptor gene expression. F Immunol 1986; 137: $150-4$. 
30 Kaulfersch W, Fiocchi C, Waldmann TA. Polyclonal nature of the intestinal mucosal lymphocyte populations in inflammatory bowel disease. A molecular genetic evaluation of the immunoglobulin and T-cell antigen receptors. Gastroenterology 1988; 95: 364-70.

31 Janossy G, Tidman N, Selby WS, et al. Human T lymphocyte of inducer and supressor type occupy different microenvironments. Nature 1980; 288: 81-3.

32 James SP, Fiocchi C, Graeff AS, Strober W. Phenotypic analysis of lamina propria lymphocytes. Predominance of helper-inducer and cytolytic T-cell phenotypes and

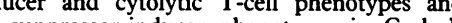
deficiency of suppressor-inducer phenotypes in Crohn's disease and control patients. Gastroenterology 1986; 91 1483-9

33 James SP. Remission of Crohn's disease after human immunodeficiency virus infection. Gastroenterology 1988; 95: 1667-9. 34 Rodgers VD, Fassett R, Kagnoff MF. Abnormalities in intestinal mucosal T cells in homosexual populations including those with the lymphadenopathy syndrome and acquired immunodeficiency syndrome. Gastroenterology 1986; 90: 552-8.

35 Lockhart-Mummery HE, Morson BC. Crohn's disease (regional enteritis) of the large intestine and its distinction from ulcerative colitis. Gut 1960;1: 87-105. 